\title{
A novel method of grafting facial nerve defects resulting from parotidectomy
}

\author{
Shim Ching MSc MD ${ }^{1}$, Achilleas Thoma MD FRCSC FACS ${ }^{1,2}$, \\ Stuart Archibald MD FRCSC ${ }^{2}$, Stanley Jackson MD FRCSC ${ }^{2}$
}

S Ching, A Thoma, S Archibald, S Jackson. A novel method of grafting facial nerve defects resulting from parotidectomy. Can J Plast Surg 2002;10(2):53-55.

The sacrifice of the facial nerve is an uncommon consequence of parotidectomy for cancer resection. In the cases described here, the facial nerve was necessarily resected due to an infiltrating tumour. Seven cases of facial nerve sacrifice that were reconstructed with a novel, sural nerve construct are presented.

The sural nerve construct facilitates facial nerve reconstruction, especially in the case of multiple branch involvement and a short, proximal nerve stump. Evaluation of these cases shows acceptable facial nerve function following this technique. The use of this technique may prove advantageous in any instance of nerve grafting where multiple nerve branches are encountered.

Key Words: Construct; Facial nerve; Nerve graft; Parotidectomy

\section{Nouvelle technique de greffe du nerf facial à la suite d'une parotidectomie}

RÉSUMÉ : Rarement une parotidectomie pour cause de cancer entraînet-elle la destruction du nerf facial. Dans les cas ici décrits, la résection du nerf facial a été rendue nécessaire par la présence d'une tumeur infiltrante. Voici sept cas de reconstruction du nerf facial à l'aide du nerf saphène externe au moyen d'une nouvelle technique.

La greffe à l'aide du nerf saphène externe facilite la reconstruction du nerf facial, surtout dans les cas d'atteinte de plusieurs branches ou de moignon proximal court. L'évaluation des patients ainsi traités fait état d'un fonctionnement acceptable du nerf facial. La nouvelle technique peut s'avérer avantageuse lorsque l'intervention touche plusieurs branches nerveuses.

Divisions of ${ }^{1}$ Plastic Surgery and ${ }^{2}$ Head and Neck Surgery, Department of Surgery, St Joseph's Hospital, and McMaster University, Hamilton, Ontario

Correspondence and reprints: Dr Achilleas Thoma, 206 James Street South, Suite 101, Hamilton, Ontario L8P 3A9. Telephone 905-523-0019, fax 905-523-0229, e-mail athoma@mcmaster.ca 
$\mathrm{T}_{\mathrm{re}}^{\mathrm{h}}$

he incidence of malignancy in parotid tumours is reported at $18 \%$ (1). Resection of the facial nerve during parotidectomy, usually due to an infiltrative tumour, is reported at $6 \%(2)$. A resulting facial nerve palsy is a devastating deformity, causing serious aesthetic and functional deficits. Where primary facial nerve repair is not possible, nerve grafts offer the best chance for recovery after nerve resection.

The branching pattern of the facial nerve, however, usually necessitates multiple grafts. Proximal resections may leave a single, short nerve stump that is not amenable to multiple nerve grafting. This problem is worsened when the proximal facial nerve stump can be isolated only within the fallopian canal of the temporal bone.

We present seven cases of facial nerve defects that resulted from surgical resection during parotidectomy. These cases were treated with the novel technique of facial nerve grafting that is presented here.

\section{METHODS}

Lengths of harvested sural nerve were cut according to the gaps in the deficient branches of the facial nerve (Figure 1, left). The proximal ends of the sural nerve grafts were sutured together, leaving the distal ends free (Figure 1, right). A neuroraphy between the proximal end of the construct and the facial nerve stump was performed using an epineurial repair with 9-0 nylon sutures under the operating microscope. The distal ends of the construct were then joined to the corresponding distal stumps (Figure 2).

Seven cases of parotid tumours were identified by retrospective chart review. Four of these cases were available for follow-up. The remaining three patients could not be assessed because they were deceased at the time of followup. Facial nerve function was assessed by two independent observers by using the Toronto Facial Grading System (TFGS) (3). The TFGS measures resting symmetry, voluntary movement and synkinesis. The score ranges from 100 (normal) to zero. The TFGS was used in favour of other
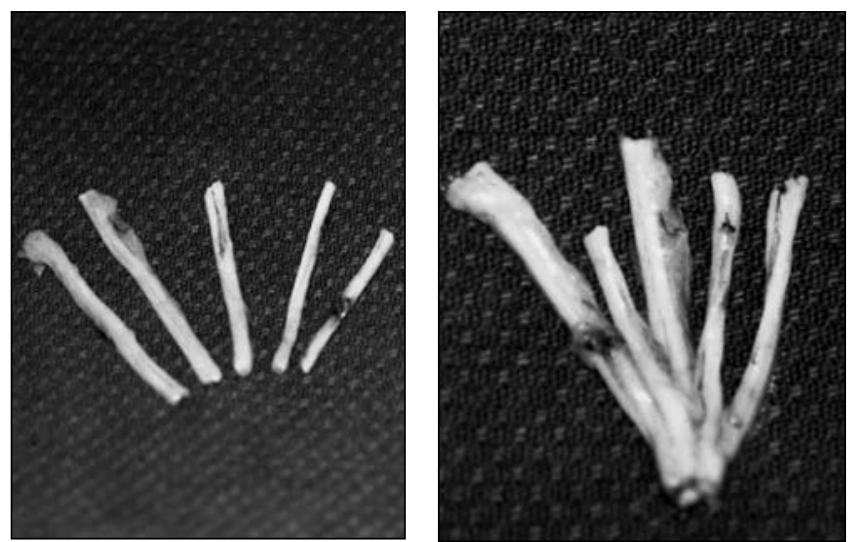

Figure 1) Left Sural nerve graft divided into segments corresponding to the defects of the facial nerve branches. Right Sural nerve graft construct

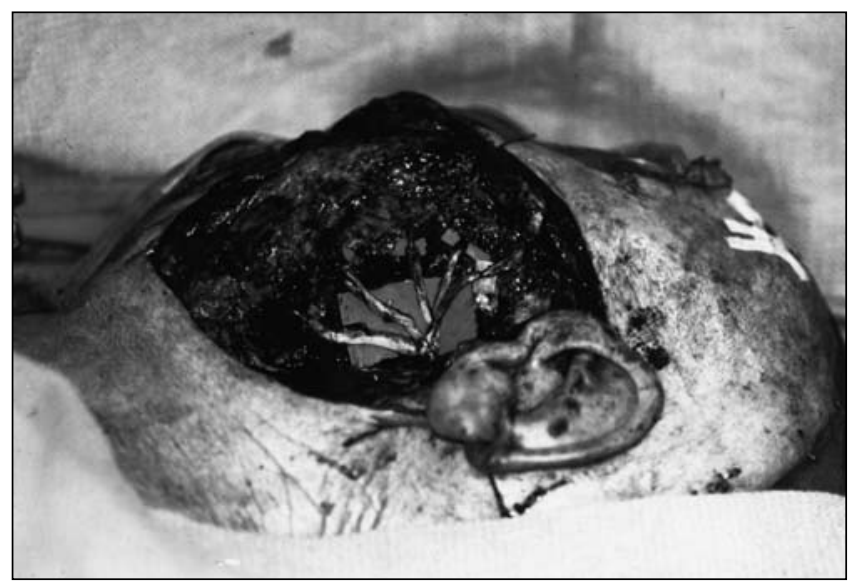

Figure 2) Intraoperative photograph of the sural nerve graft construct after microsurgical coaptation

grading scales due to its ease of use and high interobserver reliability (4).

TABLE 1

Summary of cases in which facial nerves were reconstructed with sural nerve graft construct

\begin{tabular}{|c|c|c|c|c|c|}
\hline Patient & Age (years) & Date of surgery & Diagnosis & $\begin{array}{l}\text { Number of } \\
\text { cable grafts }\end{array}$ & $\begin{array}{c}\text { Toronto Facial } \\
\text { Grading System } \\
\text { score }\end{array}$ \\
\hline ME & 59 & March 23, 1998 & Adenocarcinoma & 2 & 53 \\
\hline$H G$ & 73 & December 15, 1997 & Melanoma & 2 & 30 \\
\hline PB & 32 & May 2, 1995 & Squamous carcinoma & 4 & 58 \\
\hline IM & 57 & October 21, 1985 & Neurilemoma & 4 & 49 \\
\hline MB & 74 & September 4, 1998 & Adenocarcinoma & 5 & NA \\
\hline JN & 75 & January 7, 1997 & Squamous carcinoma & 5 & NA \\
\hline JS & 80 & July 17,1990 & Squamous carcinoma & 5 & NA \\
\hline
\end{tabular}

NA Not available 

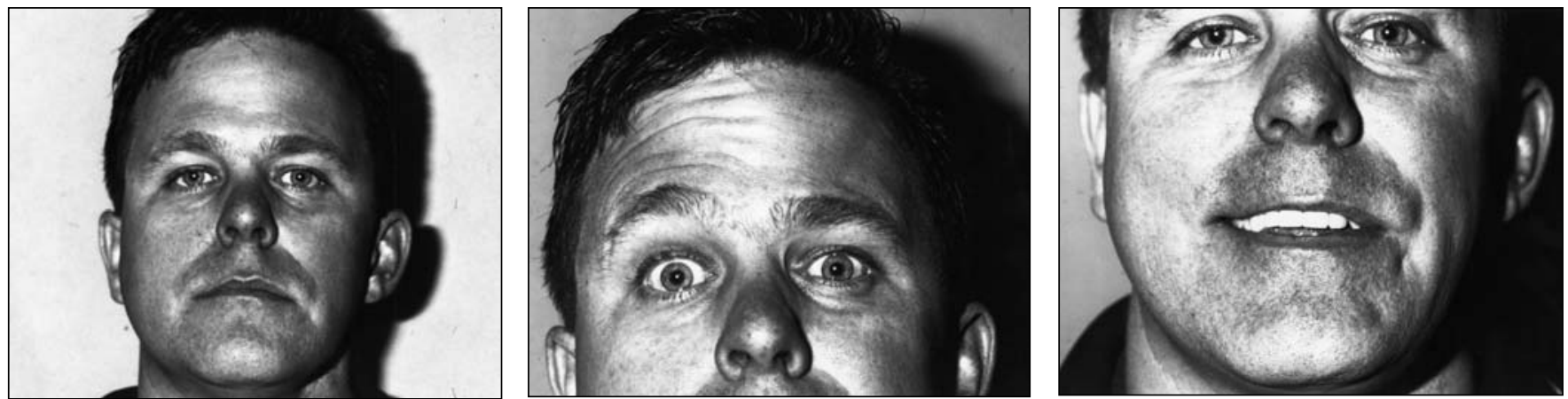

Figure 3) Left Patient (PB) showing good resting symmetry. Middle Some weakness of the left frontalis muscle. Right Good voluntary movement on smiling

\section{RESULTS}

A summary of the cases in which surgeries were performed between 1985 and 1987 is presented in Table 1. The following illustrative case demonstrates the technique used.

\section{Case 1 presentation}

$\mathrm{PB}$, a 32-year-old man, presented with a painless left parotid mass. No preoperative nerve weakness was noted. The patient underwent a left parotidectomy and left modified neck dissection. Intraoperatively, the main trunk of the facial nerve at the bifurcation was found to be densely adherent to the tumour. Resection resulted in four distal stumps and a 3 to $4 \mathrm{~mm}$ proximal remnant. A frozen section of the mass indicated the presence of squamous cell carcinoma. A $20 \mathrm{~cm}$ segment of sural nerve was harvested and cut into four portions, each corresponding to the defects in the facial nerve. The temporal branch measured $2 \mathrm{~cm}$, the zygomatic branch measured $3 \mathrm{~cm}$, the buccal branch measured $3 \mathrm{~cm}$ and the mandibulocervical branch measured $3 \mathrm{~cm}$.

At five-year follow-up, acceptable resting symmetry and good voluntary muscle movement were observed (Figure 3), and moderate synkinesis was seen. The patient's TFGS score was 58 of a possible 100 .

\section{CONCLUSIONS}

In conclusion, we found that this novel method of nerve grafting facilitates facial nerve reconstruction. This technique addresses the difficulties with multiple branch involvement and proximal facial nerve resection. The use of this technique proved to be especially advantageous when facial nerve resection resulted in a short, inaccessible proximal facial nerve stump. This construct may also be used in any circumstance that necessitates the reconstruction of multiple nerve branches.

ACKNOWLEDGEMENTS: The authors thank Dr JM Nedzelski for his help with the Toronto Facial Grading System and Ms K Veltri for her manuscript review and technical assistance.

\section{REFERENCES}

1. Dykun RJ, Deitel M, Borowy ZJ, Jackson S. Treatment of parotid neoplasms. Can J Surg 1980;23:14-9.

2. Kerrebijn JD, Freeman JL. Facial nerve reconstruction: outcome and failures. J Otolaryngol 1998;27:183-6.

3. Ross BG, Fradet G, Nedzelski JM. Development of a sensitive clinical facial grading system. Otolaryngol Head Neck Surg 1996;114:380-6.

4. Kayhan FT, Zurakowski D, Rauch SD. Toronto Facial Grading System: interobserver reliability. Otolaryngol Head Neck Surg 2000;122:212-5. 